Abstracta Iranica Abstracta Iranica

Revue bibliographique pour le domaine irano-aryen

Volume 29 | 2008

Comptes rendus des publications de 2006

\title{
"The Future of Afghanistan ». Parameters, printemps 2006, pp. 4-19.
}

\section{Anicée Van Engeland}

\section{(2) OpenEdition}

1 Journals

\section{Édition électronique}

URL : http://journals.openedition.org/abstractairanica/32902

DOI : 10.4000/abstractairanica.32902

ISSN : 1961-960X

Éditeur :

CNRS (UMR 7528 Mondes iraniens et indiens), Éditions de l'IFRI

\section{Édition imprimée}

Date de publication : 15 mai 2008

ISSN : 0240-8910

\section{Référence électronique}

Anicée Van Engeland, « «The Future of Afghanistan ». Parameters, printemps 2006, pp. 4-19. », Abstracta Iranica [En ligne], Volume 29 | 2008, document 396, mis en ligne le 15 septembre 2008, consulté le 26 septembre 2020. URL : http://journals.openedition.org/abstractairanica/32902 ; DOI : https://doi.org/10.4000/abstractairanica.32902

Ce document a été généré automatiquement le 26 septembre 2020.

Tous droits réservés 


\title{
"The Future of Afghanistan ». Parameters, printemps 2006, pp. 4-19.
}

\author{
Anicée Van Engeland
}

1 L'A. estime que depuis la chute des Talibans, l'Afghanistan a fait des progrès importants vers une démocratisation. Les élections présidentielles et parlementaires se sont déroulées de manière attendue et la reconstruction a respecté la majeure partie des objectifs des Accords de Bonn. Néanmoins les objectifs concernant la fin du conflit et le rétablissement de la paix et de la stabilité ne sont pas encore réalisés. Par conséquent, l'A. estime que le pays se trouve à une nouvelle croisée des chemins, pris entre les opportunités qui s'offrent et les combats incessants. Les efforts politiques réalisés pourraient être victimes de ces derniers. Cet article analyse les opportunités et défis que connaît le pays aujourd'hui.

\section{INDEX}

Thèmes : 13.2. Afghanistan

\section{AUTEURS}

\section{ANICÉE VAN ENGELAND}

European University Institute - Florence 